\title{
Lamotrigine-induced Drug Reaction with Eosinophilia and Systemic Symptoms (DRESS)
}

\author{
Karim Nathan, ${ }^{1}$ Abhishek Agarwal, ${ }_{1}^{1}$ Brian Gable, ${ }^{1}$ Miles McFarland ${ }^{2}$
}

${ }^{1}$ Department of Internal Medicine, Cooper University Hospital, Camden, New Jersey, USA

${ }^{2}$ Department of Pathology, Cooper University Hospital, Camden, New Jersey, USA

\section{Correspondence to}

Dr Karim Nathan, nathan-karim@cooperhealth.edu

Accepted 21 May 2015
CrossMark

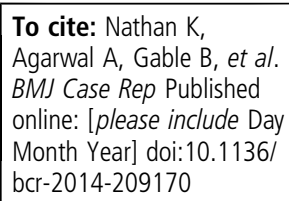

\section{DESCRIPTION}

A 59-year-old woman was transferred from another hospital for evaluation of fever and systemic rash. The patient stated that she noticed the morbilliform rash, 3 weeks earlier, diffusely throughout her body, sparing her palms and soles. Her primary care provider started her on levofloxacin $500 \mathrm{mg}$ daily. She took no other medications. The rash progressed in the next 2 weeks with subsequent desquamation and painful, erythaematous blister formation. She also reported of systemic symptoms including malaise, fatigue and dyspnoea. She revealed that 3 weeks prior to onset of the rash, she was started on lamotrigine and was taking $50 \mathrm{mg}$ daily at the time of her presentation. On physical examination, a desquamating erythaematous rash was seen over her face, lips, torso and extremities (figure 1). She was febrile to $38.2^{\circ}$. There was no lymphadenopathy, facial oedema or respiratory distress. Laboratory results revealed peripheral eosinophilia (14.8\%), alanine and aspartate transaminase elevations of 128 and 69, respectively, and creatinine of 1.9. Allergy testing was not performed. A skin biopsy was obtained from her right leg, which revealed subepidermal bullous formation with increased eosinophils and neutrophils (figure 2). She was diagnosed with Drug Reaction with Eosinophilia and Systemic Symptoms (DRESS) based on RegiSCAR inclusion criteria. These criteria include fever $>38^{\circ} \mathrm{C}$, enlarged lymph nodes at a minimum of two sites, involvement of at least one internal organ, blood count abnormalities, hospitalisation, a reaction suspected to be drug-related, acute rash, lymphocytes or eosinophils above the laboratory limits and platelets below the laboratory limits; at least three of the first four of these criteria are required to make the diagnosis. ${ }^{1}$ Her lamotrigine was discontinued and she was started on

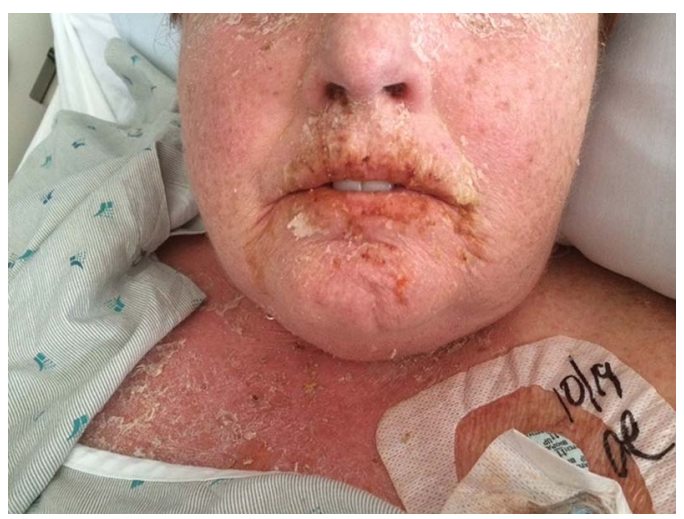

Figure 1 Desquamating rash (erythroderma) involving the face and chest.

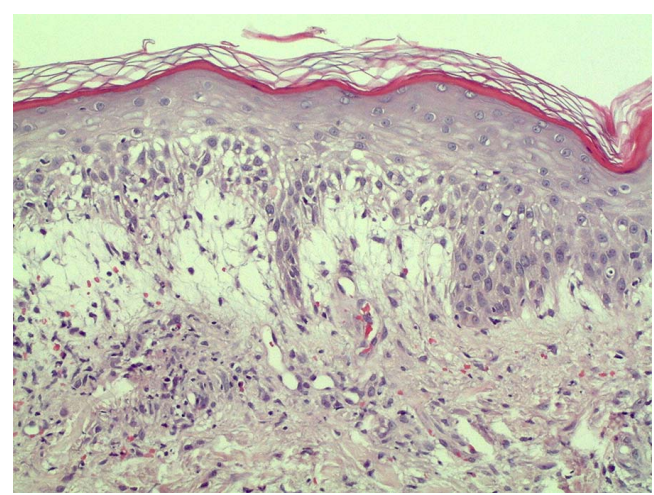

Figure 2 Spongiosis in basal epidermis with vacuolisation of cells near base of epidermis (compare to squamous epithelium on right side of picture), as well as superficial dermal oedema ( $\times 200, H \& E)$.

systemic steroids, initially intravenous methylprednisolone $60 \mathrm{mg}$ twice daily and later oral prednisone $1 \mathrm{mg} / \mathrm{kg} /$ day. The case was reported to the Food and Drug Administration. Her symptoms improved dramatically 2 days after presentation. Her $\mathrm{Cr}$ trended down to 1.3, and her diffuse rash began to resolve, with decreasing fatigue and malaise. By 6 weeks, her rash had resolved completely and she was back to her usual state of health.

\section{Learning points}

- Drug Reaction with Eosinophilia and Systemic Symptoms (DRESS) syndrome is an often difficult to diagnose condition; it has myriad manifestations and can involve virtually any organ. It is associated with numerous drugs, including lamotrigine, which is one of the first line treatments for epilepsy. ${ }^{2}$

- Histologic findings in DRESS are non-specific and may include lymphocytic infiltrate with or without eosinophils. ${ }^{3}$

- DRESS syndrome may have a mortality of up to $10 \%$ if untreated. Management consists of identifying and halting the offending agent, as well as prompt initiation of systemic corticosteroids. Patients should be followed-up for resolution of organ involvement. ${ }^{4}$

Acknowledgements The authors thank Adil Mansoor, Medical Student, Rowan School of Osteopathic Medicine.

Contributors MM prepared the histological images and wrote the accompanying captions. 


\section{Images in...}

Competing interests None declared.

\section{Patient consent Obtained.}

Provenance and peer review Not commissioned; externally peer reviewed.

\section{REFERENCES}

1 Fiszenson-Albala $\mathrm{F}$, Auzerie $\mathrm{V}$, Mahe $\mathrm{E}$, et al. A 6-month prospective survey of cutaneous drug reactions in a hospital setting. Br J Dermatol 2003;149:1018-22.
2 Choudhary S, McLeod M, Torchia D, et al. Drug Reaction with Eosinophilia and Systemic Symptoms (DRESS) syndrome. J Clin Aesthet Dermatol 2013;6: 31-7.

3 Kardaun SH, Sidoroff A, Valeyrie-Allanore L, et al. Variability in the clinical pattern of cutaneous side-effects of drugs with systemic symptoms: does a DRESS syndrome really exist? Br J Dermatol 2007;156:609-11.

4 Cacoub P, Musette P, Descamps V, et al. The dress syndrome: a literature review. Am J Med 2011;124:588-97. Web.

Copyright 2015 BMJ Publishing Group. All rights reserved. For permission to reuse any of this content visit http://group.bmj.com/group/rights-licensing/permissions.

BMJ Case Report Fellows may re-use this article for personal use and teaching without any further permission.

Become a Fellow of BMJ Case Reports today and you can:

- Submit as many cases as you like

- Enjoy fast sympathetic peer review and rapid publication of accepted articles

- Access all the published articles

- Re-use any of the published material for personal use and teaching without further permission

For information on Institutional Fellowships contact consortiasales@bmjgroup.com

Visit casereports.bmj.com for more articles like this and to become a Fellow 